\title{
28 Research Square \\ Hymenobacter Humicola sp. nov., Isolated from Soil in South Korea.
}

\section{Tuvshinzaya Damdintogtokh}

Seoul Women's University

Jaewoo Bai

Seoul Women's University

Myung Kyum Kim ( $\sim$ biotech@swu.ac.kr)

Seoul Women's University https://orcid.org/0000-0003-4098-1520

\section{Research Article}

Keywords: Hymenobacteraceae, Hymenobacter, Novel species, Taxonomy

Posted Date: May 13th, 2021

DOl: https://doi.org/10.21203/rs.3.rs-504350/v1

License: (c) (1) This work is licensed under a Creative Commons Attribution 4.0 International License. Read Full License 


\section{Abstract}

Two novel bacterial strains, designated as $\mathrm{BT} 186^{\top}$ and $\mathrm{BT} 505$, were isolated from a soil sample collected in South Korea and characterized. Both strains were Gram-stain-negative, rod-shaped, aerobic, circular, convex, and had red-colored colonies. $16 \mathrm{~S}$ rRNA sequence analysis indicated that strains $\mathrm{BT}^{\mathrm{T}} 186^{\top}$ and BT505 belong to a distinct lineage within the genus Hymenobacter (family Hymenobacteraceae, order Cytophagales, class Cytophagia, phylum Bacteroidetes, kingdom Bacteria). Both strains were closely related to Hymenobacter norwichensis DSM $15439^{\top}$ (98.3\% 16S rRNA gene similarity), Hymenobacter aquaticus JCM $31653^{\top}$ (96.8\%), and Hymenobacter perfusus LMG26000 ${ }^{\top}(96.5 \%)$. The strain BT186 was found to have the MK-7 as the major respiratory quinone. The major polar lipid of strain $\mathrm{BT}^{186^{\top}}$ was identified to be phosphatidylethanolamine (PE). The major cellular fatty acid profiles of strain BT186 ${ }^{\top}$ were $\mathrm{C}_{16: 1} \omega 5 c(24.3 \%)$, iso- $\mathrm{C}_{15: 0}(20.3 \%)$ and summed feature $3\left(\mathrm{C}_{16: 1} \omega 6 c / \mathrm{C}_{16: 1} \omega 7 c\right)(19.9 \%)$. Characterization based on polyphasic analysis indicated that strains $\mathrm{BT}_{186^{\top}}$ and $\mathrm{BT} 505$ represent novel species of the genus Hymenobacter and the name Hymenobacter humicola sp. nov. is proposed. The type strain of Hymenobacter humicola is $\mathrm{BT}^{1} 186^{\top}$ (= KCTC $72338^{\top}=$ NBRC $\left.114968^{\top}\right)$.

\section{Introduction}

The genus Hymenobacter was first described by Hirsch et al. (1999) and then corrected by Buczolits et al. (2006) and Han et al. (2014) allocated to the family Hymenobacteraceae (Munoz et al. 2017), order Cytophagales and class Cytophagia. At the time of writing (April 2021), the genus comprises 89 species with validly published names (https://lpsn.dsmz.de/genus/hymenobacter). Recently, novel strains of genus hymenobacter have been discovered from different sources including cold environments, such as air sampling in maritime Antarctica (Roldan et al. 2020), abandoned lead-zinc mine (Feng et al. 2020), arctic station (Dahal et al. 2020), regoliths in Antarctica (Sedlacek et al. 2020), lake sediments (Wang et al. 2020), the bark of ginkgo tree (Cha et al. 2020), ubiquitous weedy grass Setaria viridis (Chhetri et al. 2020) and soil (Jang et al. 2021; Lee et al. 2021).

In the present study, we conducted phylogenetic analysis, phenotypic, genotypic, and chemotaxonomic characterization to determine the taxonomic position of strains $B T 186^{\top}$ and $B T 505$. The results

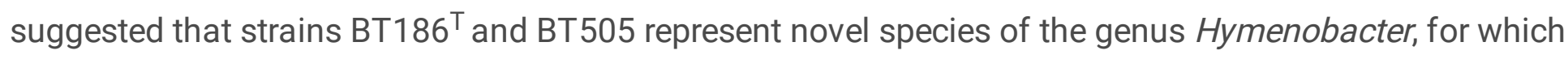
the name Hymenobacter humicola sp. nov. is proposed.

\section{Materials And Methods}

\section{Strain isolation}

Two novel strains designated as $\mathrm{SBT} 186^{\top}$ and $\mathrm{BT} 505$, respectively, were isolated from a soil sample collected at Jungangro ( $35^{\circ} 59^{\prime} 0^{\prime \prime} \mathrm{N}, 126^{\circ} 43^{\prime} 0^{\prime \prime} \mathrm{E}$ ) located in Gunsan City, South Korea. After one week of incubation at $25^{\circ} \mathrm{C}$ on Reasoner's $2 \mathrm{~A}$ (R2A) agar medium (Difco), single colonies were picked and 
subcultured using the same medium at least two times to obtain pure colonies. The new bacterial cultures were routinely subcultured on R2A agar at $25^{\circ} \mathrm{C}$, maintained at $4{ }^{\circ} \mathrm{C}$, and stored in $10 \%(\mathrm{w} / \mathrm{v})$ glycerol suspension at $-80^{\circ} \mathrm{C}$ before use.

\section{Morphology, physiology, and biochemical analysis}

Cell morphologies of new isolates were observed using transmission electron microscopy (JEOL, JEM1010) using the negative staining method. The Gram-staining reaction was performed using a kit, following the manufacturer's instructions (bioMérieux). Catalase activity was determined by adding $3 \%$ $(\mathrm{w} / \mathrm{v}) \mathrm{H}_{2} \mathrm{O}_{2}$ solution and oxidase activity was examined using $1 \%(\mathrm{w} / \mathrm{v})$ tetramethyl-p-phenylenediamine diamine. (Cappuccino and Sherman 2002). The bacterial growth of strains BT186 ${ }^{\top}$ and BT505 was tested on Reasoner's 2A (R2A) agar, Luria-Bertani (LB) agar, Tryptic Soy Agar (TSA) Nutrient Agar (NA), and MacConkey (MAC) agar, respectively. Growth at $10,15,20,25,30$ and $30^{\circ} \mathrm{C}$ was assessed under various $\mathrm{pH}$ conditions (5 to 9, $1 \mathrm{pH}$ intervals) and different effect of $\mathrm{NaCl}$ concentrations (1\%to $5 \%$ [w/v \%], $1 \%$ intervals). Enzyme activities, assimilation of carbon sources, acid production from substrates and other physiological characteristics were determined by inoculating API 20NE, API ZYM and API ID32GN strips performed according to the manufacturer's instructions (bioMérieux).

\section{Phylogenetic analysis}

For phylogenetic analysis, the $16 \mathrm{~S}$ rRNA genes were amplified using two universal primers $9 \mathrm{~F}$ and $1512 \mathrm{R}$ (Weisburg et al. 1991). The PCR products were purified and sequenced using universal primers 337F, 518R, 785F, and 926R (Macrogen). The 16S rRNA gene sequences were identified by EzBioCloud server (https://www.ezbiocloud.net/). To determine the taxonomic positions of strains BT186 ${ }^{\top}$ and BT505, the 16S rRNA sequences of related taxa of the genus Hymenobacter were obtained from EzBioCloud (Yoon et al. 2017) and compared with those of strains $B T 186^{\top}$ and BT505 using the EzEditor2 program (Jeon et al. 2014). Phylogenetic trees were constructed using the MEGAX program (Kumar et al. 2016) with the neighbor-joining (NJ) (Saitou and Nei 1987), maximum-likelihood (ML) (Felsenstein 1981), and maximum-parsimony (MP) algorithms (Fitch 1971). The stability of the tree topologies was evaluated by bootstrap analysis based on the 1,000 resampling method (Felsenstein 1985). Evolutionary distances were calculated according to the Kimura two-parameter model (Kimura 1983).

\section{Genome sequencing}

The genomic DNA of strain $\mathrm{BT} 186^{\top}$ was extracted using a genomic DNA extraction kit according to the manufacturer's instruction (Solgent). Then, the DNA library was prepared using the Nextera DNA Flex Library Prep Kit (Illumina) according to the manufacturer's protocol. Whole-genome sequencing (WGS) was performed using iSeq 100 and assembled by using the SPAdes software version 3.10.1 (Algorithmic Biology Lab, St. Petersburg Academic University of the Russian Academy of Sciences). The wholegenome sequence of strain $\mathrm{BT} 186^{\top}$ was deposited in GenBank (www.ncbi.nlm.nih.gov) database and annotated using the National Center for Biotechnology Information Prokaryotic Genome Annotation 
Pipeline (PGAP) (Tatusova et al. 2016). The average nucleotide identity (ANI) and digital DNA-DNA hybridization $(\mathrm{dDDH})$ values based on whole-genome sequences were calculated by using the EzBioCloud (https://www.ezbiocloud.net) and Genome-to Genome Distance Calculator (GGDC), respectively, with the recommended formula 2 (Table S1) (Meier-Kolthoff et al. 2013).

\section{Chemotaxonomic characterization}

To analyze the polar lipid, fatty acid, and lipoquinone components of strain $\mathrm{BT} 186^{\top}$, cells were grown on R2A agar at $25^{\circ} \mathrm{C}$ for three days. After then, cells were harvested and freeze-dried. The total lipids, glycolipids, phosphatidylcholine, and amino groups were separated using two-dimensional thin-layer chromatography (TLC). The polar lipid spots were detected by spraying the proper detection reagents as previously described (Komagata and Suzuki 1987; Minnikin et al. 1984). The cellular fatty acids methyl esters (FAME) of strain $\mathrm{BT}^{186^{\top}}$ were analyzed using the Sherlock Microbial Identification System V6.01 (MIS, database TSBA6, MIDI Inc) according to the protocol described by Sasser (1990). The respiratory quinone was extracted using the Sep-Pak Vac cartridges (Waters) and analyzed by high-performance lipid chromatography (HPLC) follow the previous methods (Hiraishi et al. 1996).

\section{Results And Discussion}

\section{Morphology, physiology, and biochemical characteristics}

Cells of strains BT $186^{\top}$ and BT505 were rod-shaped, Gram-stain-negative, aerobic, and non-motile. Colonies of strains $\mathrm{BT}^{186^{\top}}$ and BT505 were convex, smooth, circular, and red-colored. Cells of strains $\mathrm{BT} 186^{\mathrm{T}}$ and $\mathrm{BT} 505$ could survive at $10-30^{\circ} \mathrm{C}$ (optimum $25^{\circ} \mathrm{C}$ ) and $\mathrm{pH}$ 6.0-8.0 (optimum 6.0) on R2A agar plate. Distinct features between the newly isolated strains and reference strains were provided in Table 1. The negative reactions of strain $\mathrm{BT} 186^{\top}$ on API kits were given as supplementary tables (Table S2).

\section{Phylogenetic analysis and whole-genome sequence analysis}

Based on the 16S rRNA gene sequence similarities, strains BT186 ${ }^{\top}$ and BT505 were affiliated with the family Hymenobacteraceae and showed high sequence similarities with the genus Hymenobacter. The level of $16 \mathrm{~S}$ rRNA gene sequence similarity between the strains $B T 186^{\top}$ and $B T 505$ was $100 \%$, indicating that they represent an identical species. Both strains were closely related to H. norwichensis DSM $15439^{\top}$ (98.3\% 16S rRNA sequence similarity), H. aquaticus JCM 31653 ${ }^{\top}$ (96.8\%), and H. perfusus LMG26000 ${ }^{\top}$ (96.5\%). The $16 \mathrm{~S}$ rRNA gene sequence similarities of strains $\mathrm{BT}^{186^{\top}}$ and $\mathrm{BT} 505$ with the closely related type strains were less than $98.3 \%$ and with other Hymenobacter species were less than $96.4 \%$. These values were below $98.7 \%$ of which value is recently used as the threshold for differentiating among bacterial species (Chun et al. 2018). The other Hymenobacter species exhibited sequence similarities lower than $97.0 \%$. According to the phylogenetic tree based on the neighbor-joining, maximum-likelihood (Fig. S1), and maximum-parsimony (Fig. S2) algorithm, strains BT186 ${ }^{\top}$ and BT505 were placed within the genus Hymenobacter (Fig. 1). 
The draft genome of strain BT186 ${ }^{\top}$ was $6,019,942$ bp $(24.7 x)$ and consisted of 4,860 protein-coding genes, 54 RNA genes (7 rRNA genes, 44 tRNA genes), and 25 pseudogenes. The genome sequence of strain $B T 186^{\top}$ has been deposited in GenBank under the accession numbers NZ_JAFLQZ000000000. The DNA G+C content of strain $B T 186^{\top}$ was $57.5 \mathrm{~mol} \%$. This value was within the range of the $\mathrm{G}+\mathrm{C}$ contents for the genus Hymenobacter (55-71 mol\%) (Feng et al. 2019). The digital DNA-DNA hybridization values between strain $\mathrm{BT} 186^{\top}$ and other related type strains of genus Hymenobacterwere less than $30.2 \%$ (Table S1), which are below the cutoff (70\%) point (Meier-Kolthoff et al. 2013). Average nucleotide identity (ANI) values between strain $\mathrm{BT} 186^{\top}$ and other related type strains of genus Hymenobacterwere less than $85.6 \%$, respectively (Table S1). These values are below the ANI species threshold (95-96\% ANI value) as described by Richter and Rossello-Mora (2009).

\section{Chemotaxonomic characterization}

The fatty acid profiles of strain $\mathrm{BT} 186^{\top}$ and four reference strains were presented in Table 2 . The fatty acid profiles of strain $\mathrm{BT} 186^{\top}$ were similar to those of the most closely related three Hymenobacter strains (H. norwichensis DSM $15439^{\top}, H$. aquaticus JCM 31653' ${ }^{\top}$, and H. perfusus LMG $26000^{\top}$ ). The major cellular fatty acids of strain $B T 186^{\top}$ were iso- $C_{15: 0}$, summed feature $3\left(C_{16: 1} \omega 6 c / C_{16: 1} \omega 7 c\right)$, and $\mathrm{C}_{16: 1} \omega 5 c$. Strain $\mathrm{BT} 186^{\top}$ has larger amounts of iso- $\mathrm{C}_{16: 1} \mathrm{H}(1.8 \%)$ and $\mathrm{C}_{17: 1} \omega 6 c(3.9 \%)$ than those of other strains. In contrast, other closely related Hymenobacter species $\left(H\right.$. norwichensis DSM $15439^{\top}, H$. aquaticus JCM $31653^{\top}, H$. perfusus $\mathrm{LMG}^{\mathrm{T}} 26000^{\top}$ ) have smaller amounts of corresponding fatty acids. Strain $\mathrm{BT}_{186^{\top}}$ did not contain anteiso- $\mathrm{C}_{17: 0}$ and $\mathrm{C}_{17: 2} 2 \mathrm{OH}$ while other closely related two Hymenobacter species ( $H$. norwichensis DSM $15439^{\top}, H$. perfusus $\mathrm{LMG}^{\top} 6000^{\top}$ ) contained those fatty acids. The polar lipids of strain $B T 186^{\top}$ consisted of phosphatidylethanolamine (PE), five unknown aminophospholipids $(A P L)$, three unknown lipids $(L)$, an unknown phospholipid (PL), and one unknown aminolipid (AL) (Fig. S3).

\section{Description of Hymenobacterhumicola sp. nov.}

Hymenobacter humicola (hu.mi'co.la. L. fem. n. humus soil; L. suff. -cola (from L. masc./fem. n. incola) inhabiting; N.L. masc. n. humicola soil-inhabiting)

Cells are Gram-stain-negative, aerobic, rod-shaped, 0.9-1.8 $\mu \mathrm{m}$ in width and about 7.2-8.5 $\mu \mathrm{m}$ in length. Colonies are circular, smooth, convex, non-motile, and red-colored on Reasoner's 2A (R2A) agar plates after growth for three days at $25^{\circ} \mathrm{C}$. Growth is observed at various temperatures ranging from 10 to $30^{\circ} \mathrm{C}$ (optimum at $25^{\circ} \mathrm{C}$ ). The $\mathrm{pH}$ range for growth is 6.0-8.0 (optimum pH 6.0) on R2A agar. Cells grow on R2A agar, NA, TSA, and LB agar but not on MAC agar. Cells are positive for oxidase and catalase. Positive for alkaline phosphatase, esterase (C4) (weakly), esterase (C8) (weakly), leucine arylamidase, valine arylamidase (weakly), and cystine arylamidase by API ZYM. Positive for $\beta$-glucosidase (Esculin hydrolysis), $\beta$-galactosidase (PNPG), D-glucose (weakly), L-arabinose (weakly), D-mannose (weakly), and D-maltose by API 20NE. Positive for D-sucrose, D-maltose, D, L-lactate, glycogen, D-mannitol, D-glucose, 
D-melibiose, D-sorbitol, and L-arabinose by API ID32GN. The major polar lipid is phosphatidylethanolamine (PE). The major respiratory quinone is MK-7. The major cellular fatty acids of strain $\mathrm{BT} 186^{\top}$ are $\mathrm{C}_{16: 1} \omega 5 c(24.3 \%)$, iso- $\mathrm{C}_{15: 0}(20.3 \%)$ and summed feature $3\left(\mathrm{C}_{16: 1} \omega 6 c / \mathrm{C}_{16: 1} \omega 7 c\right)$ (19.9\%).

The whole-genome sequence of strain $\mathrm{BT} 186^{\top}$ has been deposited in GenBank under the accession number NZ_JAFLQZ000000000 (6,019,942 bp). The genome-based G+C content is $57.5 \mathrm{~mol} \%$. The GenBank accession number for the $16 \mathrm{~S}$ rRNA gene sequence of strain $\mathrm{BT}^{1} 186^{\top}$ is MW876235 (1,389 bp). The type strain $\mathrm{BT} 186^{\top}\left(=\mathrm{KCTC} 72338^{\top}=\right.$ NBRC $\left.114968^{\top}\right)$ was isolated from a soil sample collected in Jungangro ( $\left.35^{\circ} 59^{\prime} 0^{\prime \prime} \mathrm{N}, 126^{\circ} 43^{\prime} 0^{\prime \prime} \mathrm{E}\right)$, South Korea.

\section{Declarations}

\section{Acknowledgements}

This work was supported by a research grant from Seoul Women's University (2021), by a grant from the National Institute of Biological Resources (NIBR), funded by the Ministry of Environment (MOE) of the Republic of Korea (NIBR202002203), and by the support of R\&D Program for Forest Science Technology (Project No. 2021375C10-2123-BD02) provided by Korea Forest Service (Korea Forestry Promotion Institute).

We are grateful to Dr. Aharon Oren (The Hebrew University of Jerusalem, Israel) for helping with etymology.

Conflicts of interest: The authors declare that there are no conflicts of interest.

Ethical Approval: This article does not contain any studies with human participants or animals.

\section{References}

Buczolits SE, Denner BM, Ka“mpfer P, Busse HJ (2006) Proposal of Hymenobacter norwichensis sp. nov., classification of 'Taxeobacter ocellatus', 'Taxeobacter gelupurpurascens' and 'Taxeobacterchitinovorans' as Hymenobacterocellatus sp. nov., Hymenobactergelipurpurascens sp. nov. and Hymenobacterchitinivorans sp. nov., respectively and emended description of the genus Hymenobacter Hirsch et al 1999. Int J Syst Evol Microbiol 56:2189-2192. https://doi.org/10.1099/ijs.0.64371-0

Hirsch P, Ludwig W, Hethke C, Sittig M, Hoffmann B et al (1999) Hymenobacter roseosalivarius gen. nov., sp. nov. from continental Antartica soils and sandstone: bacteria of the Cytophaga/Flavobacterium/Bacteroides line of phylogenetic descent. Syst Appl Microbiol 21:374-383

Chhetri G, Kim J, Kim I, Kim H, Seo T (2020) Hymenobacter setariae sp. nov., isolated from the ubiquitous weedy grass Setaria viridis. Int J Syst Evol Microbiol 70:3724-3730 
Cappuccino JG, Sherman N (2002) Microbiology-A laboratory manual, 6th edn. Pearson Education, Inc. Benjamin Cummings, California

Chung AP, Lopes A, Nobre MF, Morais PV (2010) Hymenobacter perfusus sp. nov., Hymenobacter flocculans sp. nov. and Hymenobacter metalli sp. nov. three new species isolated from an uranium mine waste water treatment system. Syst Appl Microbiol 33:436-443

Lee JJ, Park SJ, Lee YH, Ten LN, Jung HY (2017) Hymenobacter aquaticus sp. nov., a radiation-resistant bacterium isolated from a river. Int J Syst Evol Microbiol 67:1206-1211

Jang JH, Maeng SH, Jung HY, Kim MK, Subramani (2021) G. Hymenobacter radiodurans sp. nov., isolated from soil in the Republic of Korea. Arch Microbiol 203:655-661

Lee SE, Ten LN, Park Y, Maeng S, Zhang J, Kim MK, Cha IT, Lee KE, Lee BH, Jung HY, Kim MK (2021) Hymenobacter busanensis sp. nov., radiation-resistant species isolated from soil in South Korea. Arch Microbiol 203:755-762

Oren A, Garrity GM (2020) Notification list. Notification that new names and new combinations have appeared in volume 70, part 6 of the IJSEM. Int J Syst Evol Microbiol 70:4848-4850

Sedlacek I, Pantucek R, Zeman M, Holochova P, Sedo O, Stankova E, Svec P, Kralova S, Videnska P, Micenkova L et al (2020) Hymenobacter terrestris sp. nov. and Hymenobacter lapidiphilus sp. nov., isolated from regoliths in Antarctica. Int J Syst Evol Microbiol 70:6364-6372

Chun J, Oren A, Ventosa A, Christensen H, Arahal DR et al (2018) Proposed minimal standards for the use of genome data for the taxonomy of prokaryotes. Int J Syst Evol Microbiol 68:461-466.

https://doi.org/10.1099/ijsem.0.002516

Dahal RH, Chaudhary DK, Kim DU, Kim J (2020) Hymenobacterpolaris sp. nov., a psychrotolerant bacterium isolated from an Arctic station. Int J Syst Evol Microbiol 70:4890-4896.

https://doi.org/10.1099/ijsem.0.004356

Felsenstein J (1981) Evolutionary trees from DNA sequences: a maximum likelihood approach. J Mol Evol 17:368-376. https://doi.org/10.1007/BF01734359

Felsenstein J (1985) Confidence limit on phylogenies: an approach using the bootstrap. Evolution 39:783791. https://doi.org/10.1111/j.1558-5646.1985.tb00420.x

Feng GD, Zhang J, Chen W, Wang SN, Zhu H (2020) Hymenobacterfodinae sp. nov. and Hymenobactermetallicola sp. nov., isolated from abandoned lead-zinc mine. Int J Syst Evol Microbiol 70:4867-4873. https://doi.org/10.1099/ijsem.0.004313

Feng GD, Zhang J, Zhang XJ, Wang SN, Xiong X, Zhang YL, Huang HR, Zhu HH (2019) Hymenobacter metallilatus sp. nov., isolated from abandoned lead-zinc ore. Int J Syst Evol Microbiol 269:2142-2146. 
https://doi.org/10.1099/ijsem.0.003450

Fitch WM (1971) Toward defining the course of evolution: minimum change for a specific tree topology. Syst Zool 20:406-416. https://doi.org/10.2307/2412116

Han L, Wu SJ, Qin CY, Zhu YH, Lu ZQ, Xie B, Lv J (2014) Hymenobacterqilianensis sp. nov., isolated from a subsurface sandstone sediment in the permafrost region of Qilian Mountains, China and emended description of the genus Hymenobacter. Antonie van Leeuwenhoek 105:971-978. https://doi.org/10.1007/s10482-014-0155-y

Hiraishi A, Ueda Y, Ishihara J, Mori T (1996) Comparative lipoquinone analysis of influent sewage and activated sludge by high performance liquid chromatography and photodiode array detection. J Gen Appl Microbiol 42:457-469. https://doi.org/10.2323/jgam.42.457

Jeon YS, Lee K, Park SC, Kim BS, Cho YJ, Ha SM, Chun J (2014) EzEditor: a versatile sequence alignment editor for both rRNA-and protein-coding genes. Int J Syst Evol Microbiol 64:689-691.

https://doi.org/10.1099/ijs.0.059360-0

Kimura M (1983) The Neutral Theory of Molecular Evolution. Cambridge: Cambridge University Press

Komagata K, Suzuki K (1987) 4 Lipid and cell-wall analysis in bacterial systematics. Method Microbiol 19:161-207. https://doi.org/10.1016/S0580-9517(08)70410-0

Kumar S, Stecher G, Li M, Knyaz C, Tamura K (2018) MEGA X: Molecular Evolutionary Genetics Analysis across Computing Platforms. Mol Biol Evol 35(6):1547-1549. https://doi.org/10.1093/molbev/msy096

Meier-Kolthoff JP, Auch AF, Klenk HP, Göker M (2013) Genome sequence-based species delimitation with confidence intervals and improved distance functions. BMC bioinformatics 14:60

Minnikin DE, O'Donnell AG, Goodfellow M, Alderson G, Athalye M, Schaal A, Parlett JH (1984) An integrated procedure for the extraction of bacterial isoprenoid quinones and polar lipids. J Microbiol Meth 2:233-241. https://doi.org/10.1016/0167-7012(84)90018-6

Munoz R, Rossello MR, Amann R (2017) Revised phylogeny of Bacteroidetes and proposal of sixteen new taxa and two new combinations including Rhodothermaeota phyl. nov. Syst Appl Microbiol 39:281-296. https://doi.org/10.1016/j.syapm.2016.04.004

Richter M, Rossello-Mora R (2009) Shifting the genomic gold standard for the prokaryotic species definition. Proc Natl Acad Sci USA 106:19126-19131

Roldan DM, Kyrpides N, Woyke T, Shapiro N, Whitman WB, Kralova S, Sedlacek I, Busse HJ, Menes RJ (2020) Hymenobacterartigasi sp. nov., isolated from air sampling in maritime Antarctica. Int J Syst Evol Microbiol 70:4935-4941. https://doi.org/10.1099/ijsem.0.004362 
Saitou N, Nei M (1987) The neighbor-joining method: a new method for reconstructing phylogenetic trees. Mol Bio Evol 4:406-425. https://doi.org/10.1093/oxfordjournals.molbev.a040454

Sasser M (1990) Identification of Bacteria by Gas Chromatography of Cellular Fatty Acids. MIDI Technical Note 101. Newark, DE: MIDI Inc

Tatusova T, DiCuccio M, Badretdin A et al (2016) NCBI prokaryotic genome annotation pipeline. Nucleic Acids Res 44:6614-6624. https://doi.org/10.1093/nar/gkw569

Wang C, Liu BT, Zhang R, Liu CL, Du ZJ (2020) Hymenobactersediminis sp. nov., isolated from lake sediment. Int J Syst Evol Microbiol 70:1895-1902. https://doi.org/10.1099/ijsem.0.003990

Weisburg WG, Barns SM, Pellerier DA, Lane DJ (1991) 16S ribosomal DNA amplification for phylogenetic study. J Bacteriol 173:697-703. https://doi.org/10.1128/jb.173.2.697-703.1991

Yoon SH, Ha SM, Lim J, Kwon S, Chun J (2017) A large-scale evaluation of algorithms to calculate average nucleotide identity. Antonie Van Leeuwenhoek 110:1281-1286. https://doi.org/10.1007/s10482017-0844-4

\section{Tables}

\section{Table 1. Different characteristics of strain $\mathrm{BT} 186^{\top}$ and closely related species.}

Taxa: 1, strain BT186' $; 2$, H. norwichensis DSM 15439' $; 3$, H. aquaticus JCM 31653'; 4, H. perfusus $\mathrm{LMG} 6000^{\top}$. Data of strain BT $186^{\top}$ was obtained in this study. Those of reference strains were obtained from previous papers (Buczolits et al.2006; Lee et al. 2017; Chung et al. 2010). All strains were positive for alkaline phosphatase and leucine arylamidase. All data were negative for $\beta$-glucuronidase, $\alpha$ fucosidase, L-malate, $a$-mannosidase and lipase (C14).

+, positive; -, negative; w, weak positive. 


\begin{tabular}{|c|c|c|c|c|}
\hline Characteristic & 1 & 2 & 3 & 4 \\
\hline Size ( $\mu \mathrm{m}$ long) & $7.2-8.5$ & $3.0-4.0$ & 2.6-3.1 & $3.5-5.0$ \\
\hline Size ( $\mu \mathrm{m}$ wide) & $0.9-1.8$ & 0.8 & $1.0-1.2$ & $1.0-1.5$ \\
\hline Colony color & red & brick red & reddish pink & red pink \\
\hline Oxidase & + & + & + & - \\
\hline Catalase & + & + & + & - \\
\hline \multicolumn{5}{|l|}{ Nitrate reduction } \\
\hline Nitrate reduction to $\mathrm{NO}_{2}$ & - & w & - & + \\
\hline Nitrate reduction to $\mathrm{N}_{2}$ & - & - & - & + \\
\hline Production of acid from glucose & - & w & - & + \\
\hline \multicolumn{5}{|l|}{ Enzyme activity } \\
\hline$N$-Acetyl- $\beta$-glucosaminidase & - & - & - & + \\
\hline Acid phosphatase & - & w & w & + \\
\hline Cystine arylamidase & w & - & w & + \\
\hline Esterase (C4) & w & - & w & w \\
\hline Esterase (C8) & w & w & w & + \\
\hline$a$-Galactosidase & - & - & - & + \\
\hline$\beta$-Galactosidase (PNPG) & + & - & - & + \\
\hline$a$-Glucosidase (starch hydrolysis) & - & - & - & + \\
\hline$\beta$-Glucosidase (Esculin hydrolysis) & + & w & - & + \\
\hline$\beta$-Glucosidase & - & - & - & + \\
\hline Naphtol-AS-BI-phosphohydrolase & - & w & w & + \\
\hline Trypsin & - & - & - & + \\
\hline Valine arylamidase & w & w & + & + \\
\hline \multicolumn{5}{|l|}{ Assimilation } \\
\hline L-Arabinose & w & - & - & - \\
\hline D-Maltose & + & w & + & + \\
\hline D-Mannose & + & w & - & + \\
\hline D-Sucrose & + & - & - & + \\
\hline
\end{tabular}




\begin{tabular}{|lllll|}
\hline N-Acetyl-D-glucosamine & - & - & - & + \\
\hline G+C content & $57.5 \%$ & $61.0 \%$ & $61.9 \%$ & $60.0 \%$ \\
\hline
\end{tabular}

\section{Table 2. Cellular fatty acid profiles of strain $\mathrm{BT}^{186^{\top}}$ and closely related species.}

Taxa: 1, strain BT186 ${ }^{\top} ; 2$, H. norwichensis DSM $15439^{\top} ; 3$, H. aquaticus JCM $31653^{\top} ; 4$, H. perfusus LMG26000 ${ }^{\top}$. Data of strain BT186 ${ }^{\top}$ was obtained in this study. Those of reference strains were obtained from previous papers (Buczolits et al.2006; Lee et al. 2017; Chung et al. 2010).

For unsaturated fatty acids, the double bond location was presented by counting the number from the methyl $(\omega)$ end of the carbon chain. -, trace $(<1 \%)$ or not detected. 


\begin{tabular}{|c|c|c|c|c|}
\hline Fatty acids & 1 & 2 & 3 & 4 \\
\hline \multicolumn{5}{|l|}{ Saturated } \\
\hline $13: 0$ iso & $\mathrm{TR}$ & ND & ND & $\mathrm{TR}$ \\
\hline 14:0 & $\mathrm{TR}$ & 1.6 & 1.5 & TR \\
\hline $14: 0$ iso & $\mathrm{TR}$ & $\mathrm{TR}$ & ND & TR \\
\hline 15:0 & ND & ND & ND & TR \\
\hline $15: 0$ iso & 20.3 & 18.9 & 13 & 19.4 \\
\hline 15:0 anteiso & 4.7 & 6.8 & 6.3 & 19.8 \\
\hline $15: 020 \mathrm{H}$ & $\mathrm{TR}$ & ND & ND & 1 \\
\hline $15: 0$ iso $30 \mathrm{H}$ & 2.3 & 3.1 & 1.9 & 2.1 \\
\hline 16:0 & 1.1 & 2.6 & 19.8 & TR \\
\hline $16: 0$ iso & 1.6 & $\mathrm{TR}$ & ND & 1.1 \\
\hline 16:0 $\mathrm{N}$ alcohol & ND & ND & ND & ND \\
\hline $16: 030 \mathrm{H}$ & $\mathrm{TR}$ & $\mathrm{TR}$ & 1 & TR \\
\hline $17: 0$ iso & 1.7 & 2.3 & ND & 3.3 \\
\hline 17:0 anteiso & ND & $\mathrm{TR}$ & ND & 1.5 \\
\hline $17: 22 \mathrm{OH}$ & ND & $\mathrm{TR}$ & ND & TR \\
\hline $17: 0$ iso $30 \mathrm{H}$ & 3.6 & 5 & 3 & 3.6 \\
\hline 18:0 & ND & ND & 12.5 & ND \\
\hline Unsaturated & ND & ND & ND & ND \\
\hline $15: 1$ iso $\mathrm{G}$ & $\mathrm{TR}$ & $\mathrm{TR}$ & 2.5 & $\mathrm{TR}$ \\
\hline $15: 1$ anteiso $A$ & $\mathrm{TR}$ & $\mathrm{TR}$ & ND & $\mathrm{TR}$ \\
\hline $16: 1$ iso $\mathrm{H}$ & 1.8 & 1.6 & ND & 1.3 \\
\hline $16: 1 \omega 5 c$ & 24.3 & 12.5 & 10.7 & 9.7 \\
\hline 16:1 $\omega 7 c$ alcohol & $\mathrm{TR}$ & ND & ND & TR \\
\hline $17: 1$ iso $\omega 9 c$ & ND & $\mathrm{TR}$ & ND & ND \\
\hline $17: 1 \omega 6 c$ & 3.9 & $\mathrm{TR}$ & ND & ND \\
\hline $18: 1 \omega 9 c$ & ND & ND & 1.1 & ND \\
\hline $\begin{array}{l}\text { Summed Feature } 1 \\
(15: 1 \text { iso } H / 13: 030 H)\end{array}$ & TR & ND & ND & 1.6 \\
\hline
\end{tabular}




\begin{tabular}{|lllll|}
\hline $\begin{array}{l}\text { Summed Feature } 2 \\
(16: 1 \text { iso I / 14:0 30H) }\end{array}$ & ND & ND & 1.0 & ND \\
\hline $\begin{array}{l}\text { Summed Feature 3 } \\
(16: 1 \omega 6 c / 16: 1 \omega 7)\end{array}$ & 19.9 & 9.8 & 15.4 & 11.1 \\
$\begin{array}{l}\text { Summed Feature } 4 \\
(17: 1 \text { iso I / 17:1 anteiso B) }\end{array}$ & 5.04 & 6.5 & 6.9 & 12.4 \\
$\begin{array}{l}\text { Summed Feature } 9 \\
(17: 1 \text { iso } \omega 9 c / 16: 0 \text { 10-methyl) }\end{array}$ & ND & ND & ND & TR \\
\hline
\end{tabular}

\section{Figures}

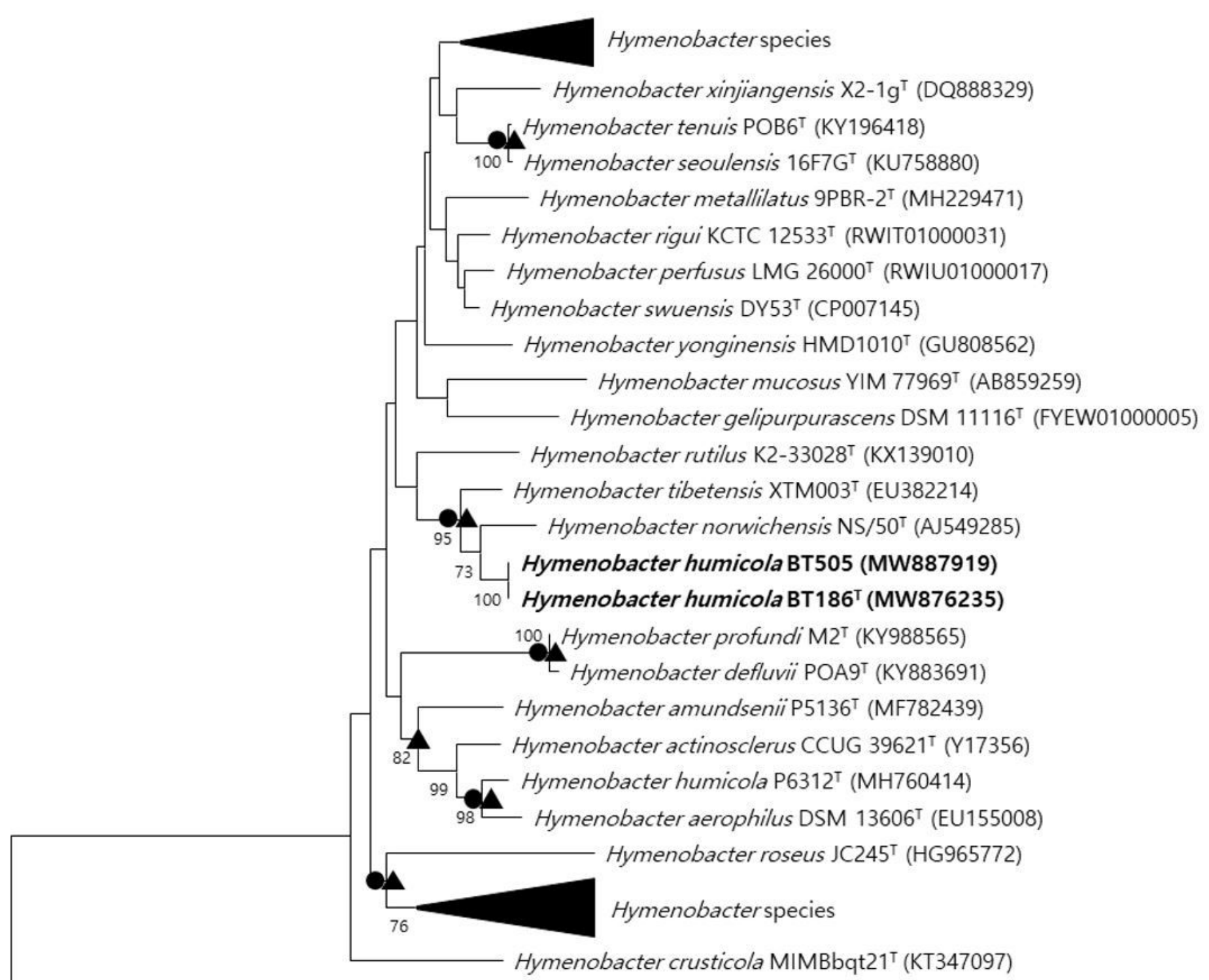

Cytophaga hutchinsoniï NBRC $15051^{\top}$ (NR 112977.1) 


\section{Figure 1}

Neighbor-joining phylogenetic tree reconstructed from a comparative analysis of 16S rRNA gene sequences showing the relationships of strains BT186T and BT505 with closely related validly published species. Bootstrap values (> 70\%) based on 1,000 replications are shown at the branch nodes. Circles indicate that the corresponding nodes were also recovered in the maximum-parsimony tree (Fig. S1). Triangles indicate that the corresponding nodes were also recovered in the maximum-likelihood trees (Fig. S2). Bar, 0.020 substitutions per nucleotide position. Cytophaga hutchinsonii NBRC 15051T were used as outgroup.

\section{Supplementary Files}

This is a list of supplementary files associated with this preprint. Click to download.

- Supplementarydata.docx 